\title{
Corporate Governance Practices of Listed Companies in India
}

\author{
Dr. Suresh. V. N. \\ Associate Professor, Maharaja's College, Ernakulum
}

\begin{abstract}
With economic liberalization, privatization and globalization, the role of individual investors/ institutional investors in the overall economic development of country has assumed overwhelming importance as the number shareholders both individual and institutional investors become voluminous. Managers are appointed by the owners to manage the company and provide maximum possible return to the shareholders and adhering to the other principle of governance in the society. But empirical evidences revealed that many of the companies, both public and private, failed miserably in the governance aspects so that the gap between owners and management has got widened.

Since, 2000 a series of legal and regulatory reforms have been initiated by the India government to transform corporate governance framework and to improve the level of responsibility and accountability of insiders, fairness in the treatment of minority shareholders and stakeholders, board practices, and transparency. In particular, the SEBI has introduced a corporate governance clause in the listing agreement (Clause 49) to address many issues in the corporate governance. However, the financial press is increasingly reporting violations of shareholders rights.

Recent events in India have put the spotlight on corporate governance practices of Indian companies. A key aspect that is being debated in the corridors of India incorporations is whether we need major regulatory changes to improve corporate governance, or whether improved standards of corporate governance could be achieved through adoption of principle based standards of conduct. Indian incorporations have generally been proactive in promulgating corporate governance regulations. From a purely regulatory stand point, India favourably with most other developing and Asian economies as far as its corporate governance rules are concerned. But good governance is characterized by a firm commitment and adoption of ethical practices by an organization across its entire value chain and in all of its dealings with a wide group of stakeholders encompassing employees, customers, vendors, regulators and share holders. At this context a study on the "Corporate Governance Practices of Listed Companies in India" is relevant.
\end{abstract}

\section{Introduction}

With the expansion of the global financial markets and shrinkage of the world economy in terms of the reach of global financial conglomerates, both the management as well as regulation of the corporate has become a herculean task. The concept of Corporate Governance is thus of utmost importance in recent times. Although corporate governance is a relatively recent phenomenon, its roots are deeply firmed in to the business world. With the progression of time, the concept is gathering further relevance and importance. Internationally, Corporate Governance has emerged as a response to many corporate failures and wide spread dissatisfaction about the functioning of the corporate sector. Corporate governance is looked upon as a distinctive brand and bench mark in the profile of corporate excellence. It is an attempt to create powerful systems by which corporate bodies can be directed and controlled by making them more accountable to the shareholders in particular and the stakeholders at large.

The subject of corporate governance leapt to global business limelight from relative obscurity after a string of collapses of high profile companies. Enron and World Com shocked the business world with both the scale and age of their unethical and illegal operations. Worse, they seemed to indicate only the tip of a dangerous iceberg. While corporate practices in the US companies came under attack, it appeared that the problem was far more widespread. Large and trusted companies from Parmalat in Italy to the multinational newspaper group Hollinger Inc., revealed significant and deep-rooted problems in their corporate governance. Even the prestigious New York Stock Exchange had to remove its director, Dick Grasso, amidst public outcry over excessive compensation. It was clear that something was amiss in the area of corporate governance all over the world.

There is no universally accepted definition of Corporate Governance due to different legal, regulatory and institutional practices followed in different countries. However for practical purposes, corporate governance refers to maximizing long term shareholders' value by following high standards of corporate management, disclosure of financial information and investor democracy. Corporate governance means establishing legal and regulatory framework that promotes credible and effective governance practices for the benefit of economy, shareholders and society as a whole. The term corporate governance involves a set of relationship between a 
company's management, its board, its shareholders and other stakeholders. There are four basic principles against which governance practice can be assessed, those of fairness, transparency, accountability and responsibility. These principles are equally relevant whether businesses are privately, publically or state owned. Corporate governance extends beyond corporate laws. Its fundamental objective is not mere fulfillment of requirements of law but by ensuring commitment of the board to transparency in managing the company and modernizing long term shareholder value. Today, corporations are not bound by geography. They function in different countries and under different legal frame works. Some of them are even bigger, in terms of their financial outlay, compared to many governments. Their power is enormous. While corporations require some degree of freedom to perform, there also is a need for some level of checks. Corporate governance is not merely about enacting legislation. It is about establishing a climate of trust and confidence. Ethical business behavior and fairness cannot be legislating. Strengthening corporate governance is fundamentally a political, social and cultural process in which government and the private sector have to synergies.

Corporate governance mechanism differs between countries. The governance mechanism of each country is shaped by its political economic and social history as also by its legal framework. Despite the difference in shareholder philosophies across countries, good governance mechanisms need to be encouraged among all corporate and non-corporate entities. While multinational organizations like the World Bank and the Asian Development Bank have evinced keen interest in the subject of corporate governance, an effective lead have been given by the OECD in evolving a set cogent principles of corporate governance which are internationally recognized to serve as good bench marks.

The term corporate governance revolves around four theories such as Agency Theory, Stakeholders Theory, Stewardship Theory and Resource Dependency Theory.

Agency theory is about identifying and describing the governance mechanism that limits the agent's (managers) self interest behavior in situations where the principal and agent have conflicting goals. From an agency perspective it is critical that, organizations have directors, who are independent of management influence in order to achieve maximum performance

The central proposition of the stakeholders' theory is that the purpose of the firm should be more widely defined than the maximization of the shareholder welfare. The social responsibility aspect of corporate governance is stressed upon when applying this theory. In the stewardship theory, the manager is looked upon as a steward whose aim is to do a good job. Therefore as opposed to the control role of the board in case of agency theory, emphasize should be on the strategic role of the board. The central thesis of the resource dependence approach is that organizations attempt to exert control over their environment by co-opting the resources needed to survive. Such a situation envisages the inter- organizational linkages, such as appointment of outside directors and board interlocks, to manage environmental contingencies.

\section{Corporate Governance in India}

The years since liberalization have witnessed wide-ranging changes in both law and regulations driving corporate governance as well as general consciousness about it. Perhaps the single most important development in the field of corporate governance and investor protection in India has been the establishment of the Securities and Exchange Board of India (SEBI) in 1992 and its gradual empowerment since then. Established primarily to regulate and monitor stock trading, it has played a crucial role in establishing the basic minimum ground rules of corporate conduct in the country.

The concerns about corporate governance stemming from the corporate scandals as well as opening up to the forces of competition and globalization gave rise to several investigations into the ways to fix the corporate governance situation in India. One of the first among such endeavors was the CII Code for Desirable Corporate Governance developed by a committee chaired by Rahul Bajaj. The committee was formed in 1996 and submitted its code in April 1998. Later SEBI constituted two committees to look into the issue of corporate governance - the first chaired by Kumaramangalam Birla that submitted its report in early 2000 and the second by Narayana Murthy three years later. The SEBI committee recommendations have had the maximum impact on changing the corporate governance situation in India. The Advisory Group on Corporate Governance of RBI's Standing Committee on International Financial Standards and Codes also submitted its own recommendations.

One of the significant developments in the field of corporate governance in India was Clause 49 of the Listing Agreement which derived mainly from the S\&O Act in USA. The SEBI issued Clause 49 in Feb. 2000, was amended in October 2004, with effect from January 1, 2006. Clause 49 had a number of requirements and recommendations and it provided a phased implementation schedule where in certain firms (Group A firms or larger firms) were expected to comply earlier than smaller firms. Initially the penalty for non-compliance was delisting (2000) then some year's later more severe financial penalties became available (2004). During the year 2004, the Securities Contract Regulation act was amended by the Government. As per Sec.23(2) of SCRA ,violations of listing agreement attract a penalty which may extend to Rs. 25 crores or imprisonment for a term extend to 10 years or with both. 
Clause 49's requirements included:

(i) Minimum percentage of independent directors (50\% or 33\% depending on whether the Chairman was an executive director),

(ii) Tightening up the definition of "independence"

(iii) Mandating the number of board meetings per year

(iv) Developing a code of conduct

(v) Imposing limits on the number of directorships a director could simultaneously hold

(vi) Enhancing the power of the audit committee by requiring financial literacy, experience and independence of its members and by expanding the scope of activities on which the audit committee had oversight

(vii) Certification by the Chief Executive Officer (CEO) and Chief Financial Officer (CFO) of financial and overall responsibility for internal controls

(viii) Enhanced disclosure obligations including accounting treatment and related party transactions, andRecent events in India have put the spotlight on corporate governance practices of Indian companies. A key aspect that is being debated in the corridors of India incorporations is whether we need major regulatory changes to improve corporate governance, or whether improved standards of corporate governance could be achieved through adoption of principle based standards of conduct. Indian incorporations have generally been proactive in promulgating corporate governance regulations. From a purely regulatory stand point, India favourably with most other developing and Asian economies as far as its corporate governance rules are concerned. But good governance is characterized by a firm commitment and adoption of ethical practices by an organization across its entire value chain and in all of its dealings with a wide group of stakeholders encompassing employees, customers, vendors, regulators and share holders. At this context a study on the corporate governance practices of listed companies in India is relevant.

Objectives of the Study

1. To study the corporate governance practices in listed companies

2. To identify the factors to improve corporate governance

\section{Methodology}

The study is based mainly on primary data. Primary data was collected through an interview schedule. The study has a sample size (purposive sampling) of 58 respondents comprising top level authorities of listed companies. The respondents include Chairman (4),CEO/MD(7),CFO(17),Executive Director(9), Independent Director(10) and Auditors(11).The industry profile of sample respondents include Chemical, Fertiliser, Petroleum and Refining, Information Technology, Electrical and Electronics and Banking and Insurance. Secondary data was also used for the study. Averages, percentages and chi-square test were employed for analysis.

IV.

Results and Discussions

Corporate governance standards have improved over the past decade, but even the best Asian markets remain far from international best practices. Regulators make it easy for companies to get away with boxticking. Markets still lack effective rules on fundamentals such as independent directors and audit committees. Meanwhile, most institutional investors are yet to invest sufficiently in voting, engagement or stewardship.

As per the Corporate Governance Watch $2010^{1}$ of the Asian Corporate Association (ACGA), India was the worst performer and its score collapsed by seven percentage points and settled at a CG market score of 49 . Among the Asian countries, Singapore regains the top spot with a CG market score of 67 which is far below the international benchmark score of 80 percent. The choice of benchmark percentage is subjective on the part of ACGA and India's position is 31 percent behind the international benchmark. This is clearly indicates the state of corporate governance climate in Indian market. Here in this section, an attempt has been made to summarize the major findings about the state of corporate governance in India.

\section{Clause 49 of Listing Agreement}

All listed companies in India must comply with the Clause 49 of the Listing Agreement. This clause provides the code of corporate governance prescribed by the Securities and Exchange Board of India (SEBI). It is revealed from the study that the state of corporate governance is not significantly improved even after the

${ }^{1}$ CLSA, CG Watch 2010, Corporate Governance in Asia 
introduction of Clause 49 of Listing Agreement. The 62 percent of the respondents are of the opinion that there exists significant scope for improvement. The Table No.1 reflects the response of the respondents.

The question regarding the strengthening of Clause 49 of the listing agreement to inculcate good governance practice, evoked mixed response from respondents. Only 17 percent of the respondents feels that the existing clause is sufficient, 54 percent of the respondents opined that clause 49 require a few changes and 29 percent noted that the clause 49 require significant revamp.

\section{Penal action against violation of Governance Regulation}

The respondents are of the opinion that the penalty levels to discipline poor and unethical governance is low. 81 percent feels that the penalty levels are very low and only 19 percent satisfied with the present level of penalty. Most of the respondents are of the opinion that strong penal action is necessary if there is any violation of governance norms.

\section{Impact of New Companies Act on Corporate Governance}

The Ministry of Corporate Affairs has proposed the New Companies Bill 2008 which aims to improve corporate governance by giving greater powers to shareholders. It proposed self regulation, minimization of regulatory approvals and increased and more transparent disclosures. The disposition of respondents with regard to the impact of new Companies Act on corporate governance shows mixed reaction. 53 percent of the respondents believe that the new Companies Act might have a limited or no impact in addressing contemporary corporate governance issues in India. 34 per cent believe that the impact will likely to be positive

\section{Corporate Governance: Principle based / Regulatory based}

The existing corporate governance legislations in India covers the fundamentals of effective corporate governance and India compares favorably with most of the developing and Asian economies as far as the adequacy of corporate governance regulations are concerned. Improved corporate governance, however, does not solely rest on control through increased regulations. What is required is a principle based approach developed on fundamentals, preventing moral fragility that is enforced through pragmatic levels of regulations. The response to the question whether the corporate governance standards are enforced through regulations or should they be principle based. 86 percent of the respondents believe that the corporate governance standards should contains moderate regulations with strong regulatory review mechanisms. Only 5 percent opined that the standards should be completely principle based and 9 percent favours the enforcement through regulations.

\section{Corporate governance concerns}

ACGA also analyzed the performance of various Asian countries towards five parameters of corporate governance such as CG Rules and Practices, Enforcement, Political and Regulatory Environment, IGAAP (accounting and auditing), and CG culture. Among the five parameters, India scored only 36 percent in enforcement which shows poor enforcement of corporate governance regulations in India. Many of the recent studies also underline this weakness. India scored maximum score in IGAAP (63) which is far below the score (88) of Singapore.

Various factors pose challenges to effective corporate governance in India. It includes lack of financial discipline, lack of respect for shareholder community weak oversight and monitoring mechanisms, inadequate independence of board members, management over ride and regulatory arbitrage. The empirical evidence pinpoints the above mentioned factors singly or jointly responsible for the corporate governance failures at the national and international levels. The disposition of respondents reveals that weak oversight and monitoring mechanisms (41 percent) is the biggest risk to corporate governance. Management override and inadequate independence stands second and third places respectively with 19 percent and 17 percent. Low financial discipline (15\%) and lack of respect to shareholders right (8\%) also contributed to make the governance system more vulnerable in India.

\section{Responsibility of the Board}

The corporate governance framework should ensure the strategic guidance of the company, effective monitoring of management by the board, and the board's accountability to the company and the shareholders. Board members should act on a fully informed basis, in good faith, with due diligence and care, and in the best interest of the company and the shareholders.

Many Indian companies in the private sector operate in a family owned culture. There has been implicit assumption amongst boards that senior managers know their job and have the best interests of companies they manage at heart. This has sometimes resulted in boards refraining from asking the difficult questions to senior managers when the company has been performing well or until there is a crisis. The selection of independent 
directors who are known to promoter directors has further compounded the problem. From a governance standpoint, boards should address the following key areas specifically concerning independent directors.

- Adoption of a transparent process for director appointments.

- Nomination committee to tackle conflict of interest in appointing independent directors.

- Alignment of needs of the company to the skills required in the board room.

- Segregation of the roles of CEO and chairman of the board of directors.

- The chairman of the board should be an independent director who plays a key role in setting the priorities of the board.

- Planning of CEO and board succession in different scenarios.

- Formal evaluation of the $\mathrm{CEO}$ and senior management team periodically.

- Peer evaluation of independent directors should be adopted.

- Impart proper training to independent directors.

Clause 49 prescribes that at least third of director board should comprise independent directors in case where the board chair is an independent director. However, where the board chair is an executive director, at least 50 percent of the board should comprise independent directors.

Majority of the respondents feel that the executive directors are not discharging their governance responsibilities properly. They often failed to spell out the fiduciary obligations including care, skill and diligence in the performance of their duties, as well as loyalty and avoidance of conflict of interest. 64 percent of the respondents believe that the executive directors are not discharging their governance responsibilities properly.

The survey also pinpoints the fact that the independent directors do not adequately challenge the executive directors and management in the process of discharging their governance responsibilities. They merely contribute towards satisfying a regulatory requirement rather than the high ideals of corporate governance. 23 percent of the respondents points out that the independent directors only make up required number of the board. 63 percent believe that at present they are satisfying only the regulatory requirement; however, empowering independent directors would enhance their performance significantly. Only 14 percent says that independent directors are an integral part of the board agenda

\section{Protection of Shareholders rights}

The corporate governance framework should protect shareholders' rights. Basic shareholder rights include the right to:

- Secure methods of ownership registration

- Transfer shares

- Obtain relevant information on a timely and regular basis

- Participate and vote in general shareholders meeting

- Elect members of the board

- Share in the profits of the corporation

In fact, corporate governance is about owners and the managers operating as the trustees on behalf of every shareholder - large or small. The principle of trusteeship is the appropriate protection for minority shareholders. The study reflects that serious effort needs to be made to address the concerns of the minority shareholders. 93 percent of the respondents air the same opinion. 7 percent of the respondents feels that minority shareholders concerns are sometimes addressed but not in the best interest of the company.

\section{Effectiveness of the Committees of the Board}

In the present scenario, companies have numerous committees of the board such as audit committee, remuneration committee, risk management committee, selection committee, ESOP committee, etc. In the study, 95 percent of the respondents reveal low and medium effectiveness of the different committees other than audit committee. Only 5 percent feels high effectiveness. Therefore there is a need for establishing a framework around the functioning of committees of boards so that their effectiveness is demonstrated.

\section{Audit Committee}

Clause 49 specifies audit committee largely comprising independent directors. Audit committee members are entrusted with the responsibility of ensuring the integrity of the company's financial statements, managing risks through internal control system and functioning of its internal audit function and regulatory compliance. While it is the duty of all directors to act in the interests of the company, the audit committee, which acts independently of executive management, has a specific responsibility of acting in the interests of stakeholders through effective oversight of the company's financial reporting and its risk management and internal control system. With respect to the effectiveness of audit committee, 68 percent of the respondents 
opine that it is low and medium and 32 percent of the respondents feel that it is high. Though the functioning of audit committee is better than other committees, still there exists enough room for improvement.

\section{Quality of Management Discussion and Analysis Report}

Clause 49 stipulates that the annual report of the company should contain management discussion and analysis report (MD\&A). This report contains the structure, developments, opportunities, threats, concerns, etc of the company. The study depicts that the quality of the report is low or medium (ie. 82 percent). Only 18 percent rate the quality of MD\&A as high or very high.

\section{Board information}

The company management should adequate information to the board members well before the board meeting. This is especially true in the case of independent board members. Then only the board members can effectively participate in the deliberations of the board. But independent directors hold executive position in other companies and this, coupled with a packed board meeting calendar, may leave them with very little time to devote to the affairs of their boards. Situation will be much worse if the independent board members may not get adequate information before a board meeting. The disposition of respondents with regard to the timing and adequacy of information reveal that 24 percent of the board members never get the right information and enough time to prepare for. 38 percent believe that board members sometimes get both enough time and the right information. 25 percent says there is scope for improvement.

\section{Corporate Social Responsibility of Companies (CSR)}

Corporate social responsibility is a concept through which organizations consider the interests of society by taking responsibility for the impact their activities have on customers, suppliers, employees, communities and the environment. This responsibility goes beyond compliance with regulations and is about organizations voluntarily taking further steps to improve the quality of life for employees as well as for the local community and society at large. The study seeks to understand whether CSR high on the agenda of companies. 79 percent of the respondents believe that CSR is not on high on the agenda of companies and 21 percent says it is high on the agenda of companies.

\section{Board responsibility to sustainability of companies}

Sustainability is an important consideration when we think of good governance in a company. The board need to ensure a high degree of sustainability in earnings, values, human and other resources and the environment in which the companies operate is gaining importance. 61 percent believe that sustainability is an important canon of corporate governance and is the board responsibility. 27 percent says that board is partly responsible and 12 percent thinks that sustainability cannot be the responsibility of the board.

\section{Stakeholders' interests in corporate governance}

The corporate governance framework should recognize the rights of stakeholders as established by law and encourage active co-operation between corporation and stakeholders in creating wealth, jobs and the sustainability of financially sound enterprise. Where stakeholders' interests are protected by law, stakeholders should have the opportunity to obtain effective redress for violation of their rights. The question regarding the adequacy of regulation, majority of the respondents (60 percent) believe that regulations are not adequate to protect the stakeholders' interest and 40 percent said it is adequate.

\section{Redress for violation of stakeholders rights}

The stakeholders can redress their grievances through number agencies. Creditors can petition the CLB, BIFR, civil and high court, as well as the Debt Recovery Tribunals for violation of their rights. Employees and environmental groups can seek redress through the civil and high court. 64 percent of the respondents are of the opinion that the redress mechanism is not effective and 36 percent think that proper mechanism is put in place to redress grievances of stakeholders.

\section{Disclosure and Transparency}

The CG framework should ensure that timely and accurate disclosure is made on all material matters regarding the corporation, including financial situation, performance, ownership, and the governance of the company. The company should disclose all material information. Analysis confirms that the quality of disclosures improved in recent years, as companies begin to understand the relationship between transparency and market valuation. However, stock exchanges' human resources are insufficient to ensure compliance. Consequently, they heavily rely on the auditors. 87 percent of the respondents think that the disclosure standards are low or medium. Only 13 percent agree that disclosure standards are high or very high. 
Information should be prepared, audited, and disclosed in accordance with high quality standards of accounting, financial and non financial disclosures, and audit. The quality of financial disclosure for listed companies is determined by DCA, SEBI and ICAI. ICAI lays down the parameters of accounting and auditing standards. According to ICAI, India is materially in conformity with International Financial Reporting Standards and International Standards on Auditing. 66 percent of the respondent says the accounting and auditing standards are medium or low and 34 percent opined that it is very high or high.

\section{Fair and timely dissemination}

Channels for disseminating information should provide for fair, timely, and cost effective access to relevant information by users. Dissemination channels include direct mailing, company websites, the stock exchanges, and press announcements. Price sensitive information must be disclosed to the exchange continuously. This is published online by the exchange. The study shows poor state of fair and timely dissemination of information by companies. 87 percent believe that the dissemination is medium or low. Only 13 percent says it is high or very high.

\section{Risk Management Practices}

Every company should have an effective risk management practices. This will prevent the crisis like situation in future. Risk management is the top oversight priority of Audit committee members.79 percent of respondent think that risk management practices need to be improved. Nobody says it is high.

\section{Factors to improve corporate governance}

Respondents were asked to rank certain factors that may result in improvement of corporate governance practices in companies. Most of them believe that better corporate governance is possible through enhancing the powers of independent directors. It is followed by better risk management and oversight process and adequate and timely disclosure of financial information. Though whistle blower policy is a non mandatory requirement in the Clause 49, it is recognized as an important driver for better governance in companies.

\section{Regulatory Arbitrage}

There are multiple agencies and regulations which regulate and control the listed corporate entities in India. The DCA, SEBI and the Stock exchanges share jurisdiction over listed companies .The result is regulatory arbitrage. This has resulted into serious regulatory enforcement problems in corporate governance. 68 percent of the respondents aired their view in favour of regulatory arbitrage.

\section{Performance linked CEO remuneration}

The question whether CEO remuneration linked to the performance of the company, 79 percent are in favour of it. 18 percent did not believe that the remuneration of CEOs should be significantly linked to company performance.

\section{Integrity and Ethical values}

Commitment to ethical professional conduct is a must for good corporate governance. The question whether integrity and ethical values given due importance by companies they represent, 22 percent says negative and only 6 percent says yes. 72 percent of the respondents believe that it needs improvement.

\section{Suggestions and Conclusion}

Following are some of the suggestions for improving corporate governance in listed companies:

- The provisions of corporate governance under the Companies Act and Clause 49 of the Listing Agreement should be harmonized to facilitate easy compliance and economy for companies.

- The DCA, SEBI and the stock exchanges share jurisdiction over listed companies. This creates a potential for regulatory arbitrage and weakens enforcement. An in-depth revision of the three tiered regulatory system would reveal whether changes in the respective roles and responsibilities of the involved institution and their supervisory functions are in order.

- The existing regulations do cover the fundamentals of effective corporative governance. However, improved corporate governance does not solely rest on control through increased regulations. What is required is a principle based approach developed on fundamentals, preventing moral fragility that is enforced through pragmatic levels of regulations.

- For good corporate governance, board should address the following key areas specifically concerning independent directors. 
> Adopt formal and transparent process for director appointment. Identification of directorial candidates will be entrusted with nomination committee comprising independent directors. This may avoid conflict of interest in appointing independent directors by the management.

$>$ Segregate the roles of CEO and the Chairman of the board. The Chairman of the board should be an independent director who plays key role in setting the priorities of the board.

$>$ Evaluate the performance of senior management team and CEO annually. This will send a clear message that the CEO is accountable to the board and introduces a healthy balance of power.

$>$ Peer evaluation of independent directors should be adopted. This will improve their individual and collective functioning.

$>$ Create a credible director training institution. Director training institutes can play a key capacity building role and expand the pool of competent candidates.

- Institutional investors could become important force to monitor insiders and play a disciplining role in the governance of companies. Encourage institutional investors who act as fiduciaries to attend shareholder meetings and vote. This might encourage shareholder activism across the board.

- Sanctions and enforcement mechanisms should be improved drastically. New fining powers to be given to SEBI and enhanced sanctions to be introduced for contravention to the listing agreement. Stock exchanges should be able to impose fines on market intermediaries that are high enough to act as credible deterrents.

- Audit committee should concentrate on the following areas.

$>$ Better understanding of risk, strategy and business models.

$>$ Understanding implications of external environment on financial forecast and performance

$>$ Monitoring senior management override of internal controls.

$>$ Effective oversight of internal and external auditors.

$>$ Ensuring that the board's direction is in the best interest of all including minority shareholders

- The board should possess diversity in skills which is fundamental to effective risk management.

- Board should have a clear understanding with senior management regarding their risk appetite in various areas and help ensure that these are articulated in design of controls, policies and procedures.

- SEBI's initiative to provide each investor with a unique client code should be implemented. A greater level of co-operation between NSE and BSE on surveillance could enhance the integrity of the market.

- Encourage companies to introduce whistle blower policies. The board members and senior managers to lead by example with respect to codes of conduct and whistle blower policies.

Corporate governance has assumed vital importance in the wake of increasing competition and economic integration. It stipulates accountability, control and reporting functions of the board of directors. It is the mechanism by which the values, principles, management policies and procedures of a corporation are inculcated and made manifest. Although the concept and form of corporate governance has been evolving for years, it inherently requires be continuously nurtured and adapted to the dynamic business environment. Today, adoption of good governance practices has emerged as an integral element of doing business.

Tougher legal and regulatory provisions of corporate governance are required to check and prevent default by companies, but unless these are implemented strictly no useful purpose would be served. The greatest challenge today is to build and restore trust among stakeholders and improve the credibility in the independence of the board. But only law cannot ensure good governance without code of conduct and self regulation. What we need today in governance of corporate entities is an attitudinal change in the people constituting the 'Management' of companies. 
Table 1- Corporate Governance Practices- Survey Findings

\begin{tabular}{|c|c|c|c|}
\hline SI.No & Factors influencing Corporate Governance & $\begin{array}{l}\text { No. of } \\
\text { Respondents\&\% }\end{array}$ & $\begin{array}{l}\text { Chi-Square } \\
\text { Value }\end{array}$ \\
\hline 1 & $\begin{array}{l}\text { Effect of Clause } 49 \text { on Corporate Governance. } \\
\text { a. No significant change } \\
\text { b. Significant change } \\
\text { C. Scope for improvement }\end{array}$ & $\begin{array}{l}8(18 \%) \\
14(24 \%) \\
36(62 \%)\end{array}$ & $20.49^{3}$ \\
\hline 2 & $\begin{array}{l}\text { Strengthening of Clause } 49 \text {. } \\
\text { a. Existing clause sufficient. } \\
\text { b. Requires a few changes } \\
\text { c. Revamp necessary }\end{array}$ & $\begin{array}{l}10(17 \%) \\
31(54 \%) \\
17(29 \%)\end{array}$ & $12.29^{\circ}$ \\
\hline 3. & $\begin{array}{l}\text { Penal action against violation of regulation } \\
\text { a. Penalty level is low } \\
\text { b. Penalty is adequate }\end{array}$ & $\begin{array}{l}47(81 \%) \\
11(19 \%)\end{array}$ & $22.34^{*}$ \\
\hline 4. & $\begin{array}{l}\text { Governance Standards. } \\
\text { a. Principle based } \\
\text { b. Moderate regulations with review mechanism } \\
\text { c. Regulatory based }\end{array}$ & $\begin{array}{l}3(5 \%) \\
50(86 \%) \\
5(9 \%)\end{array}$ & $75.34^{8}$ \\
\hline 5. & $\begin{array}{l}\text { Risk factors to Corporate Governance } \\
\text { a. Low financial discipline } \\
\text { b. Lack of respect to shareholders } \\
\text { c. Weak oversight and monitoring mechanisms } \\
\text { d. Inadequate independence } \\
\text { e. Management override }\end{array}$ & $\begin{array}{l}9(15 \%) \\
5(8 \%) \\
23(41 \%) \\
10(17 \%) \\
11(19 \%)\end{array}$ & $14.12^{*}$ \\
\hline 6. & $\begin{array}{l}\text { Executive Directors and Corporate Governance } \\
\text { Responsibility } \\
\text { a. Discharging corporate governance } \\
\text { responsibility } \\
\text { b. Not discharging corporate governance } \\
\text { responsibility }\end{array}$ & $\begin{array}{l}21(36 \%) \\
37(64 \%)\end{array}$ & $4.40^{8}$ \\
\hline 7. & $\begin{array}{l}\text { Non-executive directors and governance responsibility } \\
\text { a. Yes: make up required number on the board } \\
\text { b. Yes: empowerment would enhance } \\
\text { performance } \\
\text { c. No: integral part of board agenda }\end{array}$ & $\begin{array}{l}13(23 \%) \\
37(63 \%) \\
8(14 \%)\end{array}$ & $26.14^{*}$ \\
\hline
\end{tabular}

*Significant at 5\% level

Table 1- Corporate Governance Practices- Survey Findings

\begin{tabular}{|c|c|c|c|}
\hline Sl.No. & Factors influencing Corporate Governance & $\begin{array}{l}\text { No. of } \\
\text { Respondents\& } \\
\%\end{array}$ & $\begin{array}{l}\text { Chi-Square } \\
\text { Value }\end{array}$ \\
\hline 8. & $\begin{array}{l}\text { Board and concerns of minority shareholders satisfied } \\
\text { a. Sometimes, but not in the best interest of the } \\
\text { company } \\
\text { b. Sometimes, but in the interest of the company } \\
\text { c. } \quad \text { More often than not }\end{array}$ & $\begin{array}{l}4(7 \%) \\
16(28 \%) \\
38(65 \%)\end{array}$ & $28.51^{*}$ \\
\hline 9. & $\begin{array}{l}\text { Effectiveness of the committees of the board excluding } \\
\text { audit committee } \\
\text { a. Low effectiveness } \\
\text { b. Medium } \\
\text { c. High }\end{array}$ & $\begin{array}{l}33(57 \%) \\
22(38 \%) \\
3(5 \%)\end{array}$ & $24.26^{*}$ \\
\hline 10 & \begin{tabular}{ll}
\multicolumn{2}{l}{ Quality of Management Discussion \&Analysis Report } \\
a. & Low \\
b. & Medium \\
c. & High \\
d. & Very high
\end{tabular} & $\begin{array}{l}17(30 \%) \\
30(52 \%) \\
8(14 \%) \\
3(4 \%)\end{array}$ & 31.80* \\
\hline 11 & \begin{tabular}{ll}
\multicolumn{2}{l}{ Effectiveness of Audit committee } \\
a. & Low \\
b. & Medium \\
c. & High \\
d. & Very high \\
\end{tabular} & $\begin{array}{l}9(17 \%) \\
30(51 \%) \\
15(26 \%) \\
4(6 \%)\end{array}$ & $29.15^{*}$ \\
\hline
\end{tabular}




\begin{tabular}{|l|l|l|l|}
\hline 12. & \multicolumn{2}{|l|}{ Adequacy and timing of information to the board } & \\
& a. Adequate, but scope for improvement & $15(25 \%)$ & \\
& b. Adequate & $8(13 \%)$ & \\
& c. Sometimes & $22(38 \%)$ & \\
& d. Not adequate & $13(24 \%)$ & \\
\hline 13. & CSR in companies & $12(21 \%)$ & $19.94^{*}$ \\
& a. Yes, high on the agenda & $46(79 \%)$ & \\
& b. Not on high on the agenda & \\
\hline 14. & Stakeholders interest in Corporate governance & 1.68 \\
& a. Stakeholders interests are protected by law & $23(40 \%)$ & \\
& b. Stakeholders interests are not protected by law & $15(26 \%)$ & \\
& c. Stakeholders interests are somewhat protected & $20(34 \%)$ & \\
\hline
\end{tabular}

*Significant at 5\%

Table 1-Corporate Governance Practices- Survey Findings

\begin{tabular}{|c|c|c|c|}
\hline Sl.No. & Factors influencing Corporate Governance & $\begin{array}{l}\text { No. of } \\
\text { Respondents\& \% }\end{array}$ & $\begin{array}{l}\text { Chi-Square } \\
\text { Value }\end{array}$ \\
\hline 15. & $\begin{array}{l}\text { Grievances redress for violation of stakeholders rights } \\
\text { a. Grievance redress mechanism is effective } \\
\text { b. Grievance redress mechanism is not effective } \\
\text { c. Grievance redress mechanism is somewhat } \\
\text { effective }\end{array}$ & $\begin{array}{l}21(36 \%) \\
19(33 \%) \\
18(31 \%)\end{array}$ & 0.41 \\
\hline 16. & \begin{tabular}{ll}
\multicolumn{2}{l}{ Disclosure standards } \\
a. & Very high disclosure standards \\
b. & High disclosure standards \\
c. & Medium disclosure standards \\
d. & Low disclosure standards
\end{tabular} & $\begin{array}{l}3(5 \%) \\
5(8 \%) \\
17(30 \%) \\
33(57 \%)\end{array}$ & $36.30 *$ \\
\hline 17. & $\begin{array}{ll}\text { Fair and timely dissemination of information } \\
\text { a. } & \text { Very high level of dissemination } \\
\text { b. } & \text { High level of dissemination } \\
\text { c. } & \text { Medium level of dissemination } \\
\text { d. } & \text { Low level of dissemination }\end{array}$ & $\begin{array}{l}5(8 \%) \\
3(5 \%) \\
32(55 \%) \\
18(32 \%)\end{array}$ & $34.29 *$ \\
\hline 18. & $\begin{array}{ll}\text { Integrity and ethical values } \\
\text { a. } \quad \text { Given due consideration } \\
\text { b. } \quad \text { Considered but need improvement } \\
\text { c. } \quad \text { Not considered }\end{array}$ & $\begin{array}{l}3(6 \%) \\
42(72 \%) \\
13(22 \%)\end{array}$ & $43.76^{*}$ \\
\hline 19. & \begin{tabular}{ll}
\multicolumn{2}{l}{ Regulatory arbitrage } \\
a. $\quad$ High level of existence \\
b. $\quad$ Moderate level of existence \\
c. & No existence \\
\end{tabular} & $\begin{array}{l}8(13 \%) \\
32(55 \%) \\
18(32 \%)\end{array}$ & $15.46^{*}$ \\
\hline 20. & $\begin{array}{ll}\text { Factors to improve Corporate Governance(Ranks) } \\
\text { a. } & \text { Enhance powers of independent directors } \\
\text { b. } & \text { Improve risk management and oversight processes } \\
\text { c. } & \text { Improve financial disclosures } \\
\text { d. } & \text { Segregate position of the Chairman and CEO } \\
\text { e. } & \text { Strengthen minority shareholders rights } \\
\text { f. } & \text { Encourage whistle blower policy }\end{array}$ & $\begin{array}{l}\text { I } \\
\text { II } \\
\text { III } \\
\text { IV } \\
\text { V } \\
\text { VI }\end{array}$ & \\
\hline
\end{tabular}

*Significant at $5 \%$ level

\section{References}

[1] Balasubramanian, N., Bernard S. Black and Vikramaditya Khanna (2008), Firm-level corporate Governance in Emerging Markets: A Case Study of India, Working Paper.

[2] Bhattacharyya, Asish K and Sadhalaxmi Vivek Rao (2005), Economic Impact of Regulation on Corporate Governance: Evidence from India, Working Paper.

[3] Black, Bernard S. and Vikramaditya Khanna (2007), Can Corporate Governance Reforms Increase Firm's Market Value? Evidence from India, 4 Journal of Empirical Legal Studies 749-795.

[4] Claessens S., 2003, Corporate Governance and Development, Global Corporate Governance Forum, World Bank, Washington D.C 
[5] CLSA, CG Watch 2010, Corporate Governance in Asia

[6] Dharmapala, Dhammika and Vikramaditya Khanna (2008), Corporate Governance, Enforcement, and Firm Value: Evidence from India, Working Paper.

[7] India: Role of Institutional Investors in the Corporate Governance of their Portfolio Companies; June, 2005, Finance and Private Sector Development Unit, South Asia Region, the World Bank.

[8] Jayati sarkar and Subrata Sarkar, 2005, Multiple Board Appointments and Firm Performance in Emerging Economics: Evidence from India, Working Paper 2005-001, Indira Gandhi Institute of Development Research, Mumbai, India.

[9] Jayati Sarkar and Subrata Sarkar, 2000, Large shareholder activism in developing countries: Evidence from India, International Review of Finance, 1, pp.161-194

[10] Johnson S., P Boone,A Breach, and E. Fried man, 2000.Corporate Governance in the Asian Financial Crisis, Journal of Financial Economics, 141-186

[11] Kee-Hong Bae, H. Tan and M.Welker, 2007, International GAAP Differences: The Impact on Foreign Analysts, Working Paper, Queen University, Canada.

[12] Phil Armstrong, Chief, Global Corporate Governance Forum, Key Note Address, 10th ICSI National Award for Excellence in corporate Governance, 2010.

[13] Report on the Observance of Standards and Codes (ROSC)-Corporate Governance Country Assessment-India, 2004

[14] Saibal Ghosh, 2006, Do board characteristics affect firm performance? Firm level evidence from India, Applied Economic Letter s 13, pp.435-443

[15] The State of Corporate Governance in India: 2008, KPMG, India's Audit Committee Institute.

[16] U.Bhattacharya, H.Daouk, and M.Welker, 2003, The World Price of Earning Opacity, Accounting Review 78.

[17] Vikramaditya Khanna, 2009, Law Enforcement and Stock market Development: Evidence from India, CDDRL Working Papers, Stanford University. 